\title{
PROTECTION OF THE EUROPEAN UNION'S PUBLIC (FINANCIAL) INTEREST IN NORMATIVE BUDGETARY PRINCIPLES
}

\author{
MARCIN TYNIEWICKI
}

\begin{abstract}
The problems concerning the protection of the EU financial interest are generally discussed in the context of fighting corruption or preventing and eliminating fraud (financial irregularities). In many cases, the actions taken have ex-post character since they concern situations of inappropriate distribution (allocation) of public funds. In this article, the Author approached these problematics a bit differently because he tried to prove that already on the stage of planning (constructing) EU budget as well as during its implementation there are instruments such as normative budgetary principles which may serve to protect its financial interest ex-ante. Moreover, the primary sources of this protection should be also found in the public choice theory, functioning in the economics. Therefore, the aim of this article is to prove the following hypotheses: the basis for protection of the EU financial interest is to be found in the functioning public choice theory as well as in - being its consequence - normative budgetary principles, whose content includes duty to properly govern, and especially plan, public funds accumulated in the EU budget. Conclusions resulting from the analysis of the indicated problematics have been determined on the basis of non-reactive (non-empirical) research methods, i.e. examination of the reference literature and binding EU regulations.
\end{abstract}

\section{Keywords}

Public choice; EU budget; budget discipline; resource scarcity; financial interests

\section{JEL Classification: E62, H41, H61}

1 Doctor of Financial Law, Department of Public Finance and Financial Law, Faculty of Law, University of Bialystok, Poland. The Author specializes in local government finance, EU public finance, and public debt management. He is a member of the Regional Chamber of Account in Bialystok and the Center for Information and Research Organization in Public Finance and Tax Law of Central and Eastern Europe. Contact email: tyniewicki@uwb.edu.pl. 


\section{Introduction}

The problems concerning the protection of EU financial interest are generally discussed in the context of fighting corruption or preventing and eliminating fraud (White, 1998: 2-3; Szarek-Mason, 2010: 73; European Commission, 2016: 8-11). In many cases, the actions taken have ex-post character, since they concern situations of inappropriate distribution (allocation) of public funds. It needs to be emphasized that the duty to implement the protection of the EU financial interest has been generally determined in Art. 325 of the Treaty on the Functioning of the EU².

In this article, the Author approached these problematics a bit differently because he tried to prove that already on the stage of planning (constructing) EU budget as well as during its implementation there are instruments such as normative budgetary principles which may serve to protect financial interest ex-ante. Moreover, the primary sources of this protection should be also found in the public choice theory, functioning in the economics.

Therefore, the aim of this article is to prove the following hypotheses: the basis for protection of the EU financial interest should be found in the public choice theory functioning in the economics as well as in - being its consequence - normative budgetary principles whose content includes duty to properly govern, and especially plan, public funds accumulated in the EU budget. Referring to such stated hypotheses, the Author tried to answer the following research questions, which are essential to implement the aim of this paper:

- in what way and in what scope will the public choice theory constitute the source protecting the EU financial interest?

- in what way will the budgetary principles included in the content of legal norms be able to protect the EU financial interest?

Conclusions resulting from the analysis of the indicated problematics have been established on the basis of non-reactive (non-empirical) research methods, i.e. examination of the reference literature as well as binding EU legal regulations.

It should be generally stated that budgetary principles functioning in the EU law, i.e. rules regarding designing and functioning of the Union budget has not yet been analyzed in the aspect of financial interest protection. In the financial literature, if the problems of principles are discussed, they have descriptive character and the Authors focus mainly on the legal regulations concerning these principles as well as indicate how they are implemented (Strasser, 1992: 47-70; European Commission, 
Protection of the European Union's Public (Financial) Interest...

2014: 147-178; Lenaerts, Van Nuffel, 2011: 571-572). Often also their practical dimension is discussed.

Not without a reason, the Author used the term "normative budgetary principles" in the title of this article. It results from the fact that in the EU law these principles, on the one hand, may be separated as a matter of interpretation of the TFEU provisions and on the other hand they were enumerated in Art. 3 of the Regulation of the European Parliament and the Council (EC, Euratom) no. 966/2012 on the financial rules applicable to the general budget of the Union and repealing Council Regulation (EC, Euratom) no. 1605/2002 ${ }^{3}$, however, their list is not closed. The Treaty provisions give basis to distinguish other principles by interpretation. However bearing in mind both legal acts, the following basic budgetary principles may be indicated: unity and budgetary accuracy, annuality, financial continuity, financial autonomy, anteriority, budgetary discipline, equilibrium, unit of account, universality, specification, sound financial management, and transparency (Kosikowski, 2008: 121; Tyniewicki, 2012: 210). Due to limited publication framework the Author will not analyse all of them, but will focus only on these which in his opinion create significant norms to implement the protection of the EU financial interest, i.e. the principle of annuality and connected with it principles of anteriority and financial continuity, unity, budgetary accuracy as well as sound financial management. However, it needs to be emphasized that all enumerated principles are significant for the analyzed problematics and it even may be stated that they constitute a kind of a system protecting financial interest at the stage of budget planning, implementing and supervising.

It is also important that these principles in the process of the EU budget management, including administering its financial funds, are binding not only for the EU institutions and bodies, in particular, the European Commission which is responsible for implementing the EU budget on the basis of Art. 53/1 FR. But this process also involves the Member States, which due to the means obtained from the EU budget participate in its implementation, what results from the method of budget implementation defined as the shared management method (Art. 58/1/a FR). As a result, a large part of the funds is allocated by the Member States. With regard to the financial statement for 2016, they are responsible for implementation of more than $86 \%$ of all expenditure of the EU budget (European Commission, 2016: 37).

Budgetary principles which are to facilitate proper spending of the EU budgetary appropriations, and which are a kind of legal protection of the Union financial interest, are not autonomous instruments. Their establishment was one of the indirect consequences of the public choice theory functioning in the economics. The 
theory itself should be recognized as the primary source protecting the EU financial interest, whereas budgetary principles take the form of legal norms which should realize this protection in the practical dimension. This hypothesis was formulated at the very beginning and from proving it the Author will start further considerations.

\section{Public Choice Theory as the Primary Source Protecting the EU Financial Interest}

In the process of public funds management, there is almost always a question: how to spend them properly (optimally) taking into consideration public tasks implemented and in particular on the basis of what principles it should be done. From the axiological point of view, the source of this problem seems obvious, both in the context of public and non-public finance. It results from existing in the economics two contradictory phenomena: human limitless demands and resource scarcity which are to satisfy these demands. As a result, the theory of scarcity appears (Eklund, Hebert, 2014: 31; Murherjee, 2005: 11).

In the area of public finance, it has even stronger influence than in the private sector. The additional factor limiting public resources is their accumulation (seizure) on the basis of income which private people have at their disposal. However, the phenomenon of scarcity does not limit the process of public sector expansion, what is manifested in the willingness of public authorities to enlarge allocations range and redistribution of public funds as well as to guarantee the participation in the division of these funds to particular social groups. On the one hand, these tendencies are expressed by the law of increasing public spending, also called Wagner's law, although the causes of such situation are of diverse character: sociological, historical, political as well as economic and social (Buchanan, Musgrave, 2001: 64; Gaudemet, Molinier, 2000: 78-81). On the other hand, in the process of law-making, implementing particular financial policy, the state creates expenditure norms which are the basis for the so-called mandatory spending (Austin, 2017: 5-6), and thus are "imposed" by the introduced regulations.

Both phenomena - increasing public spending and creating mandatory spending are focused on allocations of public funds which, regarding these phenomena, faces two substantial problems, namely:

1. who do the decision-makers (public authority) represent in reality and in whose interest do they fulfill their functions?,

2. what criteria are the decision-makers (public authority) guided by when managing public funds - allocating public and social goods? (Owsiak, 1998: 71). 
Protection of the European Union's Public (Financial) Interest...

The above mentioned problems are the subject of interest of liberal public goods theory as well as public choice theory (Buchanan, 1987: 175-177; Kiefer, 1997: 15-16; Musgrave, Musgrave, 1989: 87-109; Lee, 2013; Buchanan, Musgrave, 1999; Stiglitz, 2000: 230-248), as well as of a more narrow issue - rationalizing public spending. Basically, public choice theory concerns problems of goods allocation and income redistribution selection. In other words, its content includes the issues of type, amount and quality of public goods as well as the method of paying for them. Citizens are to decide about it by means of democratic elections, thereby limiting arbitrariness and freedom of decision-making of public authorities. Such manner of expressing own election preferences matches known in the literature agency problem, which is a model of public sector functioning (Weingast, Moran, 1984: 147-192; Moe, 1984: 739777). In this model, a Principal is the society/citizens and an Agent - politicians.

Even though the public choice theory concerns problems of goods allocation and income redistribution, it should not be forgotten that these processes must be conducted according to legal regulations. Politicians who obtained a social mandate to exercise public authority, i.e. their political program was accepted by the society (voters), may implement this program within a legal framework. Only at the very end, by the implementation of this law, there is a real allocation of goods and income redistribution. Hence, the public choice theory indirectly influences establishing expenditure norms and this process is presented in the Graph below.

\section{Graph 1 Impact of Public Choice Theory on Establishing Expenditure Norms and Public Goods Allocation}

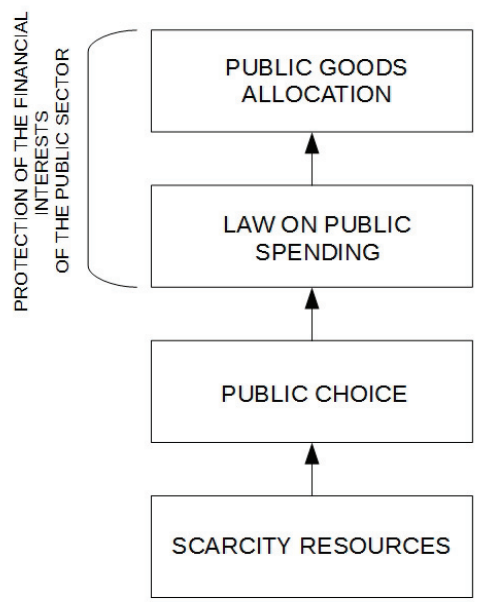

Source: Own study. 
It needs to be emphasized that even the most socially generous political programs included in the content of the established legal regulations meet limitations resulting from the mentioned resources scarcity, whose consequences are in the possibility to manufacture goods and impose the fiscal burden on the income generated from it. Ignoring this whole mechanism manifested in too expanded social programs or populistic promises together with their implementation will sooner or later cause excessive debt of the state and/or cause the economic crisis. Having this in mind, in legal systems of a lot of countries, not only those characterized by free market economy, appear regulations regarding the public spending of limiting, savings and disciplining character. How effective they are and to what extent they are enforced is a disputable issue. Also in not fully free market economic systems, with the different scope of the state interference in the market mechanism, such regulations exist, what has been noted by the Author. In this case, the sense of their existence may be questioned, but from the formal point of view, they are introduced to keep up appearances of free market mechanisms and proper functioning of the public finance system.

To summarize, the public choice theory also has its reflection in the legal norms regulating the principles of public spending. A part of these norms concerns through proper directives on planning, savings, efficiency, purposefulness or broadly understood rationalization of spending - the protection of public finance interest of a given public organization: state, international organization, etc. This theory impacts decision which are to care for these interests. Besides it should be added that both in the sphere of law-making as well as in the real actions of managing public finance, including financial decisions, the key role should play moral norms and citizenship education (For more see: Salachna, Tyniewicki, 2016: 11-20; Salachna, Tyniewicki, 2017: 81-83).

\section{Implementation of the EU Budgetary Principles in the Context of Proper Public Funds Management and Protection of the EU Financial Interest}

\subsection{Principle of Annuality as a Norm Determining Time Frame for Spending Budgetary Appropriations}

The principles of EU budget annuality is complex, also in the context of protecting the Union financial interest. In the general dimension, it defines the length of the financial year for which the budget is adopted and which begins on 1 January and ends on 31 December (Art. 313 TFEU). In the economic and management dimension it means that planning and managing budgetary appropriations take place during this period. On the other hand, in the legal dimension, it determines the episodic 
Protection of the European Union's Public (Financial) Interest...

character of the budgetary act (act including the EU budget), which after each financial year loses its Authorizing power. With regard to the EU financial economy it means limiting the possibilities to make revenue and expenditure operations because funds in the budget are "approved" for one financial year (Art. 310/2 TFEU, Art. 9 FR). This "approval" in the financial terminology means the budget authorization, i.e. giving it legal force. This fact together with the episodic character of the budget act, in reality, means temporal - limited to one year - possibility to manage funds accumulated in the EU budget. The issue of authorization is quite complex and will be discussed in 3.3. of this article.

Taking into consideration only analyzed principle of annuality, the end of financial year causes on the one hand "automatic" loss of the power to Authorize the budget act, and on the other hand - the phenomenon of expenditure expiry, what is stipulated in Art. 13/1 FR: "Appropriations which have not been used by the end of the financial year for which they were entered shall be canceled". So by virtue of law, there is a prohibition to incur expenditure after the financial year is ended. Actions against this prohibition will infringe financial discipline and will be harmful to the EU financial interest. However, in Art. 13/2-4 FR there are exceptions from the non-expiry principle consisting in the possibility to transfer expenditure.

When confronting the results of the principle of annuality and the complexity and plurality of tasks anticipated in the budget, the principle should be considered quite restrictive. The period to implement these tasks, taking into consideration the global character of the EU aims, often exceeds one financial year. Strictly obeying this rule would make it impossible to achieve these tasks effectively. An instrument which mitigates the contradictions between long-term tasks and the principle of annuality is the institution of differentiated appropriations, which includes commitment appropriations and payment appropriations. According to Art. 10/2 FR commitment appropriations cover the total cost of commitment entered into during the financial year. This category determines projected costs which are to be covered from the budget as a result of the commitments entered into the financial year. Due to their different maturity periods, it is not tantamount to the number of their real payments. It will also include the annual cost of the long-term tasks. Whereas the real amounts of budget expenditure will be reflected in payment appropriations (Art. 10/3 FR) which will include payments of legal commitments entered into the financial year or preceding financial years.

The principle of annuality is fully applied in the context of the EU multi-annual financial frameworks, i.e. financial perspectives currently adopted for seven 
years ${ }^{4}$. They belong to medium-term instruments managing EU funds (European Commission, 2008: 182). They include EU priorities which will be implemented in the indicated period with the concurrent determination of financial ceilings for their financing.

The principle of annuality, having regard to the process of multiannual financial planning in the EU, does not make an exception and is rather a supplement. On the one hand, successive annual EU budgets in terms of amounts must be in accordance with the ceilings for commitments resulting from the seven-year financial frameworks (Art. 312/3TFEU, Art. 51 FR), but on the other hand, the frameworks alone do not Authorise expenditure. Such authorization takes place as a result of adopting the budget act by the European Parliament and the Council, what has been already discussed. Therefore, it may be stated that in the EU there is a coexistence model of multiannual and annual financial planning and not their mutual exclusion (Ruśkowski, 2014: 39). Moreover, the European Commission itself believes that the sole fact of "entering" annual budgets into the multiannual frameworks should not be seen as a conflict with the principle of annuality (European Commission, 2014: 159).

Principles of anteriority and financial continuity, connected with the principle of annuality, are also significant to the protection of the EU financial interest. They constitute a protection measure for the possibility to conduct economy on the basis of the EU annual budget. In the financial doctrine through the anteriority, principle is formulated the directive according to which the budget should be adopted before the beginning of the period for which it was designated so that it could enter into force with the first day of the new financial year. Due to the episodic character of the budget and the loss of its Authorizing power with the end of the year, the EU should have possibilities to manage funds for the following year based on a new budgetary plan. From this perspective, it is a guarantee to maintain budgetary discipline. On this basis, it may be stated that the anteriority principle ensures stability and financial continuity of the Union.

In the EU law, the principle of anteriority results from a few provisions, e.g. Art. 313 and Art. 314 TFEU. The latter article regulates the procedure of adopting the general budget, which includes strict deadlines for particular stages so that it could be adopted prior to the beginning of the financial year for which it is to be binding. On the other hand, Art. 315 TFEU includes principles regarding transitional management of the financial economy (also expenditure) in the case no final budget is adopted at the beginning of a new financial year.

4 Pursuant to Art. 312/1/2 TFEU minimal period for which multi-annual frameworks should be adopted is 5 years. 
Protection of the European Union's Public (Financial) Interest...

\subsection{Budgetary Rules as Instruments Determining EU Budget Expenditure Principles}

Key principles for maintaining budgetary discipline, and in a broader sense - for protecting the EU financial interest, are also the principles of unity and budgetary accuracy. Their general frameworks result from Art. 310 TFEU, which stipulates that all revenue and expenditure of the Union should be entered in the budget for each financial year. The content of these principles is developed in the provisions of the Financial Regulation - Art. 7 and 8, respectively. In the doctrine of public finances, the principles of unity and budgetary accuracy belong to the broadly understood principle of budget comprehensiveness (completeness).

Generally, both analyzed principles are focused on the formal role of the budget act in the processes of managing appropriations accumulated in the budget. At the same time, they impact the manner in which this management should be done (i.e. according to the EU budget principle of universality ${ }^{5}$ ) and they define the legal character of the budget act, including its Authorizing power.

Pursuant to Art. 7/1 FR the principle of unity specifies whose and what revenue and expenditure are included in the EU general budget, i.e.:

1) revenue and expenditure of the Union, including administrative expenditure concerning Common Foreign and Security Policy ${ }^{6}$; in the case of this policy also operational expenditure should be included if they are covered by the budget. They may be financed directly by the Member States. If the Council decides so, then the EU budget participation is excluded",

2) revenue and expenditure of the European Atomic Energy Community.

Additionally, regarding Art. 7/2 FR, guarantees for borrowing-and-lending operations, including the European Stability Mechanism and Balance of Payment Facility operations should be entered into the EU budget.

The principle of unity does not have an absolute character. There are many cases in which the appropriations are excluded from the annual budget of the Union (European Commission, 2014: 149), in particular:

1) appropriations for borrowing-and-lending operations, but as it was indicated above the guarantees for these operations are included in the budget,

2) appropriations at the disposal of the European Development Fund,

\footnotetext{
5 Regarding the science of public finances the principle of EU budget unity is, in fact, a principle of formal unity and the principle of universality - is a principle of substantive unity.

6 Cf Art 41/1 TFEU.

7 Cf Art 41/2 TFEU.
} 
3) appropriations at the disposal of the European Investment Bank.

It needs to be emphasized that the EU budget does not include European Central Bank (ECB), but it is not an exception from the principle of unity. It is a matter of separate monetary policy independently conducted by the Central Bank and fiscal policy - mainly based on the budget, as well as having independence from the Union institutions, central, regional and local governments of the Member States according to Art. 123 TFEU. Besides in Art. 2/b of the Financial Regulation itself there is a clear indication that ECB is not a Union institution to which this regulation applies.

The second principle - budgetary accuracy is focused on the role of the EU budget, and basically of the budget act, as the main basis in the process of managing budget appropriations. This act, what has already been mentioned, constitutes the only form of Authorizing budgetary resources, what de facto means giving them legal force. As a consequence no revenue and expenditure can be implemented if they are not entered in the proper part of the budget - the so-called line in the budget (Art. 8/1 FR). It is also forbidden to commit or Authorize expenditure in the excess of the Authorized appropriations (Art. 8/2 FR).

The obligation to cover in the content of the budget the biggest number of titles on the basis of which the EU accumulates appropriations also influences the adopted method of their distribution, which was determined by the principle of universality mentioned above, also called the gross budget principle (Strasser, 1992: 48-49). This rule is mainly anchored in Art. 310/1 TFEU and its clarification is in Art. $20 \mathrm{FR}$. Its essence is to appropriate all accumulated revenue to cover all planned expenditure. So the possibility to "reserve" or connect particular revenue titles with specific expenditure is excluded. Such a way of conducting financial economy is based on the no-funding principle, known in the literature, which is to ensure the possibility to finance all and not only selected aims (tasks) of the Union, what may also be evaluated through protecting its financial interest. This rule has no absolute character because Art. 21 FR provides many exceptions.

The above mentioned Authorizing character of the budget act (the EU budget) is of fundamental significance in managing public funds, and in the broader aspect, it is essential to maintain financial discipline and protect the EU financial interest. Repeatedly in particular provisions of the Financial Regulation there is the notion of "authorization" of appropriations by the budget (Art. 2/c, 8/1-2, 9, 11) or "enter" funds into the budget (Art. 2/c, 8/1-3, 11/5). Moreover, even in the catalog of the basic notions used for the Regulation, it was defined as an: "instrument which, for each financial year, forecasts and Authorizes all revenue and expenditure considered necessary for the Union". 
Protection of the European Union's Public (Financial) Interest...

Coming back to the sole authorization of the budget, it should be stated that it is a multi-faceted issue. From the formal point of view, it means adopting the EU budget during a special legislative procedure by the Parliament and the Council pursuant to Art. 314 TFEU. However, from the tangible point of view, it means legalizing or giving other legal force to the whole content of the budget, which includes mainly revenue and expenditure. In relation to the revenue aspect, authorization means the possibility to collect revenue because as provides Art. 8/1 no revenue shall be collected unless booked to a line in the budget. To be more precise, the budget act itself does not constitute the legal basis to collect funds. It is done on the basis of other act - the Council Decision no. 2014/335/EU on the system of own resources of the EU (OJ 2014/L168/105) as well as implementing acts issued on its basis. This decision has basic significance in this process. Provisions of Art. 8/1 FR emphasize only the obligation to enter (record) collected revenue into the proper line in the budget.

On the other, taking into consideration the processes of making the expenditure, the budget authorization significantly influences maintaining financial discipline. The direct effect of the final adoption of the EU budget in the legislative procedure for Authorizing officers is on the one hand authorization (law) to manage appropriations, and on the other hand - prohibition to exceed planned expenditure. They set absolute ceilings. This particular - disciplinary character of budgetary expenditure authorization is often emphasized in the provisions of the Financial Regulation. As an example the following regulations may be indicated:

- no expenditure shall be effected unless booked to a line in the budget (Art. $8 / 1)$

- no expenditure may be committed or Authorized in the excess of the Authorized appropriations (Art. 8/2);

- an appropriation may be entered into the budget only if it is considered necessary (Art. 8/3);

- appropriations not used by the end of the financial year shall be canceled (Art. 13/1);

- the limit of the appropriations provided for in the draft budget cannot be exceeded in the case if the budget has not been adopted at the beginning of the financial year (Art. 16/2);

- the budget must be amended in the case of making the legal act with financial implications (Art. 52);

- the Commission shall implement the budget within the limits of appropriations Authorized (Art. 53/1). 
However, it should be indicated that the EU budget (the budget act) itself does not give the possibility to distribute funds. In the Union law, there is a dual legal basis rule arising from Art. 54/1 FR. Formal entering of funds into the budget is insufficient. There must be a separate legal act - basic act (e.g. regulation, directive, decision) which regulates tangible rules of spending these funds. As a result, both law-making forms - basic and budget act are necessary legalizing instruments, i.e. Authorizing to commit budget expenditure.

The Authorisation to implement budget expenditure by Authorizing officers, resulting from budget authorization, does not entitle to fully use expenditure limits. In other words, exhausting limits of the entered appropriations is not an obligation or authorization to spend "by force". A reference point in the process of expenditure management is the implementation of a provided task. Its financing should be based on the principle of sound financial management. It is generally described in Art. 310/5 TFEU and then specified in Art. 30-33 FR. Its basis are three particular rules which may be regarded as a kind of criteria for proper expenditure management, so, on the one hand, to prevent wasting and maintain discipline and on the other hand to ensure effective implementation of the established tasks.

With regard to Art. 30/1 FR appropriations should be used in compliance with the principles of economy, efficiency, and effectiveness. The economy is defined as making the resources available in due time, appropriate quality and quantity and at the best price. Efficiency, which should be identified with efficacy, means striving to achieve the best relationship between resources employed and results achieved. And effectiveness is the implementation of set objectives and intended results.

The principle of sound financial management applies also to the issue of ex-ante and ex-post evaluation of the tasks implementation (Art. 30/4), to the obligation to analyze financial consequences of all legislative initiatives submitted by the European Commission, the High Representative of the Union for Foreign Affairs and Security Policy or the Member States, which influence the Union budget (Art. $28 \mathrm{FR}$ ) as well as to ensure effective and efficient internal control of the budget implementation (Art. $32 \mathrm{FR}$ ). It also needs to be emphasized that the evaluation of financial consequences should be prepared with respect to limiting financial fraud and irregularities.

General evaluation of the above principles should suggest a conclusion that they implement a general norm expressed in Art. 310 TFEU whose aim is to obey financial discipline in the EU. Their task is also to counteract situations in which budget funds management would take place outside the budget (the so-called debudgetization) and not on the basis of the budget act. Concentrating the majority of appropriations in the budget and making expenditure based on it favors better 
Protection of the European Union's Public (Financial) Interest...

control, openness, and transparency of the EU finance as well as should lead to more effective tasks implementation. In a wider context, these principles implement the demand to protect EU financial interest, and what is important here, already on the stage of planning and gathering revenue due.

\section{Conclusions}

Taking into consideration the above analysis, a general conclusion should be formulated that protection of the EU financial interest is implemented not only by preventing and fighting financial irregularities, including corruption but also by proper designing (planning) of the EU budget which constitutes the basis for managing public funds. Instruments used in both these fields - fighting and counteracting fraud as well as financial planning form a kind of a comprehensive system of the EU financial interest protection.

The need to guarantee the protection of the financial interest of every public organization, including the EU, results from the theory of scarcity appearing in the economics. Proper and desirable resources management, also in the public sphere, is a natural process. In the public sector, the phenomenon of scarcity has the even greater impact than in the private sector. Therefore, when the citizens choose their representatives (authorities) in reality they decide what goods and in what amount should be financed from public funds (public choice theory).

Specific decisions of the citizens supporting particular political programs translate into the implemented financial (economic) policy conducted by authorities. Key instruments of this policy effectiveness are legal norms and public budgets, for whose contents are responsible politicians directly elected. Despite received social mandate, they do not have complete freedom in creating the content of the law, also regarding public expenditure, which then will be the basis for making financial decisions. In spite of sometimes generous social programs which gained social support, politicians should consider (financial) interest of the public organization which they manage regarding the scarcity phenomenon. In this context, the problem of scarcity, as well as public choice theory, indirectly translate into the way of managing public funds accumulated in budgets.

Essential legal norms regulating public budget, and especially concerning its construction and the manner of financial forecasting, constitute budgetary principles. In the EU law, they are significant, also in the legal dimension. It is reflected in the fact that main content was regulated in the Treaty law. In the financial aspect, the budgetary principles implement directives of proper (desirable) EU budget management, and thus such administration of the accumulated resources 
as to protect its financial interest starting from the planning stage. Additionally, it may be emphasized that in this last aspect also multiannual financial frameworks play a significant role.

Therefore, the issue of protecting the EU financial interest should not be related to the actions connected with counteracting and fighting irregularities or corruption but also to proper design (planning) of the Union budget and managing on its basic financial resources, which are to serve budgetary principles. A different issue worth analyzing in a separate elaboration - is how effectively these principles are implemented.

\section{References}

Austin, A.D.: Present Trends and the Evolution of Mandatory Spending, Congressional Research Service Report, 2017. www.everycrsreport.com.

Buchanan, J.M., Musgrave, R.A.: Public Finance and Public Choice, Two Contrasting Visions of the State, Cambridge: Massachusetts Institute of Technology, 2001.

Buchanan, J.M.: Public finance in the democratic process: Fiscal institutions and individual choice, Chapell Hill: University of North Carolina Press, 1987.

Eklund, R.B., Hebert, R.F.: A History of Economic Theory and Method, Long Grove, IL: Waveland Press, 2014.

European Commission: EU Budget 2016. Financial report, Luxembourg: Publications Office of the European Union, 2017. www.ec.europa.eu.

European Commission: Report from the Commission to the European Parliament and the Council. Protection of the European Union's financial interests. Fight against fraud 2016 Annual Report, Brussels: European Union, 2016. www.ec.europa.eu.

European Commission: European Union Public Finance, Luxembourg: Publication Office of the European Union, 2008.

European Commission: European Union Public Finance, Luxembourg: Publication Office of the European Union, 2014.

Etel, L., Tyniewicki, M. (eds.): Finanse publiczne i prawo finansowe. Realia i perspektywy zmian (Public finance and financial law. Realities and perspectives of changes), Bialystok: Temida 2, 2012.

Gaudemet, P.M., Molinier, J.: Finanse publiczne (Public finance), Warszawa: PWE, 2000.

Kiefer, D.: Macroeconomic policy and public choice, Berlin: Springer, 1999.

Kosikowski, C.: Financial Law of the European Union, Bialystok: Temida 2, 2008.

Lenaerts, K., Van Nuffel, P.: European Union Law, London: Sweet \& Maxwell, 2011.

Lee, D.R.: Public Choice, Past, and Present. The Legacy of James M. Buchanan and Gordon Tullock, New York: Springer New York, 2013.

Mukherjee, S.: Modern economic theory, New Delhi: New Age International, 2005. 
Protection of the European Union's Public (Financial) Interest...

Moe, T.M.: The New Economics of Organization, American Journal of Political Science no. 28 (1984).

Musgrave, R.A., Musgrave, P.B.: Public Finance in Theory and Practice, India: McGrawHill Education, 1989.

Owsiak, S.: Finanse publiczne. Teoria i praktyka (Public finance. Theory and practice), Warszawa: PWN, 1998.

Report from the Commission to the European Parliament and the Council. Protection of the European Union's financial interests. Fight against fraud 2016 Annual Report, Brussels: European Union, 2016. www.ec.europa.eu.

Ruśkowski, E. (eds.): Roczność i wieloletniość w finansach publicznych (Annuality and mutliannuality in public finance), Warszawa: Lex a Wolters Kluwer business, 2014.

Salachna, J.M., Tyniewicki, M.: Communication and the financial decisions made by public authorities, Prawo Budżetowe Państwa i Samorządu (Budget Law of the State and Local Governments) no. 4(5) (2017).

Salachna, J.M., Tyniewicki, M.: Moralność jako element podejmowania decyzji finansowych w sektorze publicznym (Morality as a factor in financial decisions making within the public sector), Prawo Budżetowe Państwa i Samorządu (Budget Law of the State and Local Governments) no. 3(4) (2016).

Strasser, D.: The Finances of Europe, Luxembourg: Office for Official Publications of the European Communities, 1992.

Szarek-Mason, P.: The European Union's Fights Against Corruption. The Evolving Policy Towards the Member States and Candidate Countries, New York: Cambridge University Press, 2010.

Stiglitz, J.E.: Economics of the public sector, New York: Norton, 2000.

Weingast, B.R., Moran, M.: The Congressional-Bureaucratic System: A Principal-Agent Perspective, Public Choice no. 44 (1984).

White, S.: Protection of the Financial Interests of the European Communities: The Fight against Fraud and Corruption, Hague: Kluwer Law International, 1998.

EU: Treaty on the Functioning of the European Union: no. 2012/C 326/01.

EU: Regulation of the European Parliament and the Council (EC, Euratom): no. 966/2012 on the financial rules applicable to the general budget of the Union and repealing Council Regulation (EC, Euratom) no. 1605/2002.

EU: Council Decision: no. 2014/335/EU on the system of own resources of the EU (OJ 2014/ L168/105). 